\title{
Association of juvenile disciform maculopathy with HLA B15
}

\author{
A. CRAANDIJK AND G. M. T. SCHREUDER \\ From the Eye Hospital, The Hague, The Netherlands
}

SUMMARY Twenty patients with juvenile disciform maculopathy (JDM), which clinically cannot be differentiated from presumed ocular histoplasmosis, are presented. Histocompatibility antigen typing showed an increase in HLA B15, but this increase was not significant with respect to the corrected $\mathrm{P}$-value. We are reporting our results in the hope of encouraging those who have cases of JDM in Europe to consider histocompatibility antigens and in particular HLA B15.

The HLA antigen distribution in 20 patients with juvenile disciform maculopathy (JDM) is presented and compared with the HLA typing of a very similar disease, namely, presumed ocular histoplasmosis. Juvenile disciform maculopathy is a clinical entity and patients with JDM show the following characteristics: haemorrhagic disciform detachment of the macular or perimacular region; small well-defined choroidal or pigment epithelial lesions of the posterior pole or at the papillary margin; no involvement of the anterior segment; clear vitreous; prevalence mainly in the age group of 20 to 40 years; negative histoplasmin skin test.

The disease has many names-for example, haemorrhagic exudative retinitis (Hausschild, 1974), ocular histoplasmosis syndrome (Braunstein et al., 1974), multifocal choroiditis (presumed histoplasmosis) (Notting et al., 1975), focal haemorrhagic choroiditis (Schildberg and Wessing, 1975), juvenile haemorrhagic maculopathy (Oosterhuis et al., 1976), and juvenile haemorrhagic macular degeneration or 'histoplasmosis-like choroiditis' (de Laey, 1978).

In effect all these are cases of JDM and cannot be differentiated from presumed ocular histoplasmosis on the clinical picture alone. Since Histoplasma capsulatum is rarely seen in Europe (Ellis and Schlaegel, 1973), and since patients with JDM have negative histoplasma skin tests, the relationship with histoplasma must be questioned.

\section{Materials and methods}

On the basis of the characteristics listed above 20 patients with JDM were selected, all being con-

Correspondence to Dr A. Craandijk, Oogziekenhuis, Leyweg 295, S'-Gravenhage, The Netherlands firmed by fluorescein angiography. The patients were otherwise healthy, young (average age 35, range 14 to 42 years), and had been observed for an average of 3.9 years (range 0.25 to 8 years). From each of the 20 patients $20 \mathrm{ml}$ of freshly drawn blood was heparinised ( 2 drops of Thromboliquine) and sent within hours to the HLA typing laboratory of the Department of Immunohaematology at Leiden University.

HLA typing was performed according to the National Institutes of Health lymphocyte microcytotoxicty technique (Ray et al., 1976) with a set of 120 typing sera. A group of 4000 healthy Dutch blood donors served as a control population for the HLA A and B specificities. Out of this group 1824 were also typed for HLA C locus groups Cw1 to 5 .

\section{Results}

Among the 20 cases of JDM 29 HLA A, B, and C locus specificities could be defined (Table 1). An increase in HLA B15 was observed in 8 patients $(40 \%)$ as compared to $15.7 \%$ in the control group. These patients, 3 males and 5 females, with an average age of 35 years (range 15 to 42 years) were observed for an average duration of 3.2 years (range 0.25 to 5 years). All patients had reached the inactive scar stage with the exception of 1 male, who after 3 months' observation still showed an active subretinal neovascularisation. The increase in HLA B15 when compared with the control population gave $\chi^{2}=7 \cdot 76, P=0.00534, \quad R R=3.6$, and corrected $\mathrm{P}=\mathbf{0} \cdot 14$ (Woolf, 1955; Edwards, 1974). The uncorrected $P$ value is just significant, whereas the corrected $P$ value is not.

In presumed ocular histoplasmosis the frequency of the HLA B7 antigen was shown to be statistically 
Table 1 HLA antigen distribution in patients with juvenile disciform maculopathy and in controls

\begin{tabular}{|c|c|c|c|c|}
\hline & \multicolumn{2}{|l|}{$\begin{array}{l}\text { Patients } \\
\mathbf{n}=20\end{array}$} & \multicolumn{2}{|c|}{$\begin{array}{l}\text { Controls } \\
\mathrm{n}=4000\end{array}$} \\
\hline & Number & Per cent & Number & Per cent \\
\hline HLA A 1 & 5 & 25 & 1254 & $31 \cdot 3$ \\
\hline A2 & 11 & 55 & 2141 & $53 \cdot 5$ \\
\hline A3 & 8 & 40 & 1222 & $30 \cdot 5$ \\
\hline A9 & 3 & 15 & 806 & $20 \cdot 2$ \\
\hline A 10 & 2 & 10 & 275 & 6.9 \\
\hline Al1 & 0 & 0 & 409 & $10 \cdot 2$ \\
\hline A28 & 1 & 5 & 375 & $9 \cdot 4$ \\
\hline Aw19 & 4 & 20 & 811 & $20 \cdot 2$ \\
\hline B5 & 5 & 25 & 410 & $10 \cdot 2$ \\
\hline B7 & 7 & 35 & 1175 & $29 \cdot 4$ \\
\hline B8 & 4 & 20 & 932 & $23 \cdot 3$ \\
\hline B12 & 3 & 15 & 1014 & $25 \cdot 3$ \\
\hline B13 & 0 & 0 & 196 & 4.9 \\
\hline B14 & 0 & 0 & 143 & $3 \cdot 6$ \\
\hline B15 & 8 & 40 & 627 & $15 \cdot 7^{*}$ \\
\hline Bw16 & 1 & 5 & 256 & 6.4 \\
\hline B17 & 1 & 5 & 323 & $8 \cdot 1$ \\
\hline B18 & 2 & 10 & 258 & 6.4 \\
\hline Bw21 & 0 & 0 & 102 & $2 \cdot 6$ \\
\hline Bw22 & 0 & 0 & 210 & $5 \cdot 3$ \\
\hline B27 & 1 & 5 & 312 & $7 \cdot 8$ \\
\hline Bw35 & 5 & 25 & 698 & $17 \cdot 4$ \\
\hline B37 & 0 & 0 & 151 & $3 \cdot 8$ \\
\hline \multirow[t]{2}{*}{ B40 } & 1 & 5 & 705 & $17 \cdot 6$ \\
\hline & & & \multicolumn{2}{|l|}{$\mathrm{n}=1824$} \\
\hline Cw1 & 0 & 0 & 131 & $7 \cdot 2$ \\
\hline Cw2 & 1 & 5 & 318 & $17 \cdot 5$ \\
\hline Cw3 & 9 & 45 & 680 & $37 \cdot 3$ \\
\hline Cw4 & 6 & 30 & 501 & $27 \cdot 3$ \\
\hline Cw5 & 1 & 5 & 135 & $7 \cdot 4$ \\
\hline
\end{tabular}

$* \chi^{2}=7 \cdot 76$ (Woolf, 1955)

significant (Godfrey et al., 1978; Braley et al., 1978). In our cases the HLA B7 antigen occurred in 7 cases, 3 males, and 4 females, average age 37 years (range 24 to 46 years) and were observed during 4.6 years (range 3 to 7 years). All 7 cases have arrived in the inactive scar stage and have shown no activity during the last year.

The frequency of HLA B7 in JDM was $35 \%$ as compared to $29.4 \%$ in the control group and falls within normal limits.

\section{Discussion}

The clinical features of JDM have been recognised in Europe for at least 10 years. Even in the USA $11 \%$ of the patients with presumed ocular histoplasmosis have negative skin tests (Ellis and Schlaegel, 1973). These may be cases of JDM.

Recent publications have shown a statistically significant increase in the frequency of HLA B7 antigen in cases with the presumed ocular histoplasmos syndrome (Godfrey et al., 1978; Braley et al., 1978). The HLA B7 frequency was not significantly increased in our cases of JDM.

Flaage et al. (1977) found no specific HLA antigen frequencies in their 9 cases of juvenile haemorrhagic maculopathy. In our 20 cases of JDM an increase in HLA B15 is not significant with respect to the corrected $P$ value, but it is certainly worthwhile continuing to determine the histocompatibility antigens in cases of JDM.

\section{References}

Braley, R. E., Meredith, T. A., Aaberg, T. M., Koethe, S. M., and Witkowski, J. A. (1978). The prevalence of HLA-B7 in presumed ocular histoplasmosis. American Journal of Ophthalmology, 85, 859-861.

Braunstein, R. A., Rosen, D. A., and Bird, A. C. (1974). Ocular histoplasmosis syndrome in the United Kingdom. British Journal of Ophthalmology, 58, 893-898.

Edwards, J. H. (1974). HLA and disease. Detection of associations. Journal of Immunogenetics, 1, 249-257.

Ellis, F. D., and Schlaegel, T. F. (1973). Geographic distribution of presumed histoplasmic choroiditis. American Journal of Ophthalmology, 75, 953-956.

Flaage, T., Bratberg, S., and Syrdalen, P. (1977). Haemorrhagic maculopathy in young adults. Acta Ophthalmologica, 55, 489-495.

Godfrey, W. A., Sabetes, R., and Cross, D. E. (1978). Association of presumed ocular histoplasmosis with HLAB7. American Journal of Ophthalmology, 85, 854-854.

Hausschild, E. (1974). Zum Krankheitsbild der Chorioretinitis centralis haemorrhagica. Klinische Monatsblätter für Augenheilkunde, 5, 661-668.

Laey, J. J. de (1978). Juvenile haemorrhagic macula degeneration or 'histoplasmosis-like' choroiditis. Documenta Ophthalmologica, 45, 181-189.

Notting, J. G. A., Deutman, A. F., and von der Werf, P. J. P. (1975). Erscheinungsbild und Behandlung makulärer Läsionen bei multifokaler Choroiditis (presumed histoplasmosis). Klinische Monatsblätter für Augenheilkunde, 166, 629-636.

Oosterhuis, J. A., Go-Sennema, A. A., and Craandijk, A. (1976). Juvenile haemorrhagic maculopathy. Ophthalmologica, 173, 407-409.

Ray, J. G., Pedersen, P. D., Hare, D. B., and Mullally, D. (1976). Manual of Tissue Typing Techniques. Lymphocyte microtoxicity technique, pp. 81-82. Bethesda, Maryland, National Institutes of Health Dhew Publication No. NIH 77-545.

Schlildberg, P., and Wessing, A. (1975). Die fokale hämorrhagische Choroiditis. Klinische Monatsblätter für Augenheilkunde, 166, 651-659.

Woolf, B. (1955). On estimating the relation between blood groups and disease. Annals of Human Genetics, 19, 251-253. 